\title{
PENGARUH TERAPI MENULIS EKSPRESIF TERHADAP TINGKAT KECEMASAN REMAJA KORBAN BULLYING
}

\author{
Susanti Niman*, Monika Saptiningsih, Clara Tania \\ Sekolah Tinggi Ilmu Kesehatan Santo Borromeus \\ *nathanmama11@gmail.com
}

\begin{abstract}
ABSTRAK
Tindakan bullying menimbulkan kecemasan dan harga diri rendah pada korban. Remaja SMA korban bullying yang menjadi takut, dan malas pergi sekolah. Tujuan penelitian untuk diketahuinya pengaruh terapi menulis ekspresif terhadap tingkat kecemasan. Kecemasan merupakan respons emosional ditandai dengan rasa takut, tegang dan gelisah. Menulis ekspresif adalah metode menulis untuk mengungkapkan pengalaman emosional. Metode penelitian menggunakan kuantitatif dengan desain pre-experimental one group pretest-posttest. Instrumen menggunakan kuesioner Depression, Anxiety, Stress Scale (DASS-42) dengan mengambil subskala anxiety. Teknik sampel menggunakan total sampling sebanyak 20 korban bullying yang menderita kecemasan. Analisa dilakukan dengan uji paired t-test. Hasil : p- value $=0,000(<0,05)$. Ada pengaruh terapi menulis ekspresif terhadap tingkat kecemasan.
\end{abstract}

Kata kunci: kecemasan, korban bullying, terapi menulis ekspresif

\section{EFFECT OF EXPRESSIVE WRITING THERAPY TOWARDS THE LEVEL OF ANXIETY ANALYSIS OF VICTIMS OF BULLYING}

\begin{abstract}
Bullying causes anxiety and low self-esteem to the victim. Bullying teenagers who become scared, and are lazy to go to school. The purpose of this study was to determine the effect of expressive writing therapy on anxiety levels. Anxiety is an emotional response characterized by fear, tension and anxiety. Expressive writing is a method of writing to express emotional experiences. The research method uses quantitative with pre-experimental one group pretest-posttest design. The instrument uses the Depression, Anxiety, Stress Scale (DASS-42) questionnaire by taking the anxiety subscale. The sampling technique uses a total sampling of 20 bullying victims who suffer from anxiety. Analysis is done by paired t-test. Results: p-value $=0,000(<0.05)$. There is an effect of expressive writing therapy on anxiety levels.
\end{abstract}

Keywords: anxiety, victims of bullying, expressive writing therapy

\section{PENDAHULUAN}

Pada masa remaja sering dijumpai permasalahan yang berhubungan dengan penolakan oleh teman sebaya. Penolakan oleh teman sebaya biasanya dilakukan dengan adanya tindakan bullying (Niman, 2018). Perilaku bullying dikenal sebagai masalah sosial yang ditandai dengan suatu tindakan yang agresif, tindakan yang mengandung unsur kekerasan secara fisik maupun verbal. Perilaku bullying sering ditemukan pada kalangan anakanak sekolah (Niman, 2018). UNICEF (2014) menjelaskan bahwa 1 dari 3 anak perempuan dan 1 dari 4 anak laki-laki pernah mengalami kasus kekerasan. Berdasarkan data tersebut , kekerasan terhadap anak perempuan lebih sering terjadi dibandingkan dengan anak lakilaki. Plan International dan International Center for Research on Women bulan Maret 2015 menyatakan bahwa 84\% anak Indonesia mengalami tindak kekerasan. Data Komisi Perlindungan Anak Indonesia (KPAI) tahun 2011 hingga Agustus 2014, terhitung 369 pengaduan masalah bullying. Pusat Pelayanan Terpadu Pemberdayaan Perempuan dan Anak (P2TP2A) Bandung menjelaskan bahwa sampai pada 18 Juli 2016 terdapat 76 kasus kekerasan terhadap anak dan hampir semua kabupaten/ kota di Jawa Barat terdapat kekerasan terhadap anak. 
Kasus bullying pada anak faktanya sangat banyak, mengakar, terwariskan dari generasi ke generasi dan sering kurang terpantau oleh orang tua dan sekolah. Seringkali anak bermain, mengejek, memukul pada teman sebayanya, sebagai bentuk hiburan bagi dirinya sendiri dalam bermain dan bersosialisasi (KPAI, 2015). Bullying adalah penyalahgunaan kekuatan dalam bentuk verbal, fisik dan perilaku sosial yang membahayakan fisik dan mental korban. Tindakan bullying dapat melibatkan individu atau kelompok secara langsung maupun melalui dunia maya, yang dilakukan secara terang-terangan maupun secara tersembunyi. Bullying dapat memperpanjang rantai kekerasan. Anak yang pernah dibully memiliki kecenderungan untuk melakukan tindakan bullying kepada orang lain, bahkan termasuk kepada anaknya sendiri di masa yang akan datang (Unicef, 2015).

Kecenderungan remaja laki-laki melakukan bullying sebanyak 56,4\% (Niman, 2018). Korban bullying cenderung memiliki harga diri yang rendah, dan aspek citra diri yang tidak dapat mereka perlihatkan sehingga mereka bisa menjadi target dari pelaku (Latifah, 2012). Bullying berdampak pada diri remaja. Dampak tindakan bullying adalah rasa minder terhadap teman-teman sebayanya dan dengan masyarakat yang ada di sekitarnya serta memiliki perasaan cemas. Dampak lain dari bullying yaitu, harga diri rendah. Harga diri rendah yang dialami membuat remaja tidak percaya diri ketika berada pada lingkungan masyarakat (Andri, 2010). Apabila tindakan bullying terjadi dalam waktu yang lama, dapat menyebabkan seorang anak mengalami gangguan emosional dan depresi (Dewi, 2012). Ansietas adalah kekhawatiran yang tidak jelas dan menyebar, berkaitan dengan perasaan tidak pasti dan tidak berdaya. Ansietas dialami secara subjektif dan perasaan ansietas ini muncul bila kita memiliki perasaan khawatir dan tegang atau takut bila berada di bawah tekanan atau stress dalam menghadapi situasi (Videbeck, 2014). Terapi menulis ekspresif berguna untuk individu yang sulit mengungkapkan permasalahannya secara verbal dan bagi seseorang yang mengalami stress, kegelisahan, kecemasan ringan, serta depresi ringan (Dewi, 2012). Rahmawati (2014) memaparkan bahwa pemberian terapi menulis ekspresif dapat menurukan tingkat stres. Hal ini dikarenakan selama menulis subjek dapat meluapkan ekspresi emosinya.

Berdasarkan hasil wawancara dengan Dinas Pendidikan Kabupaten Bandung Barat didapatkan adanya kasus bullying di SMA Negeri dimana korban bullying mengundurkan diri dari sekolah. Hasil wawancara kepada guru BP/BK di sekolah SMA terdapat 5 kasus perilaku bullying dalam bentuk senioritas antara kakak kelas kepada adik kelasnya. Penyebab dari perilaku tersebut hanya karena masalah pacar. Pihak sekolah sudah memanggil pelaku dan korban dari tindakan bullying lalu menyelesaikan masalah tersebut dengan membicarakannya secara baik-baik bersama dengan guru BP/BK dan wali kelas dan belum sampai pada pemanggilan orang tua.

Wawancara terhadap korban bullying disebutkan bahwa penyebab terjadinya karena masalah pacar, salah paham antara kakak kelas dan adik kelas. Korban bullying lainnya mengungkapkan sering diejek oleh temanteman satu kelasnya karena kekurangan fisiknya. Tindakan bullying yang diterima oleh korban membuat korban memiliki perasaan ingin balas dendam. Ketika korban mendapatkan perilaku bullying, korban hanya bisa menangis, bercerita kepada orang tua, teman, atau guru BK/BP. Penelitian ini bertujuan untuk mengetahui pengaruh terapi menulis ekspresif terhadap tingkat kecemasan melalui penelitian kuantitatif.

\section{METODE}

Penelitian dilakukan dengan kuantitatif. Desain yang digunakan pre-experimental one group pretest-posttest. Sampel yang diambil sebanyak 20 korban bullying yang mengalami kecemasan. Instrumen kecemasan yang digunakan Depression, Anxiety, Stress Scale (DASS-42) dengan mengambil subskala anxiety. 


\section{HASIL}

Tabel 1.

Tingkat kecemasan korban bullying sebelum dilakukan terapi menulis ekspresif $(n=20)$

\begin{tabular}{llc}
\hline Tingkat Kecemasan & $\mathrm{f}$ & $\%$ \\
\hline Normal & 0 & 0 \\
\hline Ringan & 2 & 10 \\
\hline Sedang & 7 & 35 \\
\hline Berat & 6 & 30 \\
\hline Sangat Berat & 5 & 25 \\
\hline
\end{tabular}

Tabel 2.

Tingkat kecemasan korban bullying setelah dilakukan terapi menulis ekspresif $(n=20)$

\begin{tabular}{llc}
\hline Tingkat Kecemasan & f & $\%$ \\
\hline Normal & 5 & 25 \\
\hline Ringan & 8 & 40 \\
\hline Sedang & 7 & 35 \\
\hline Berat & 0 & 0 \\
\hline Sangat Berat & 0 & 0 \\
\hline
\end{tabular}

Tabel 3

Tingkat kecemasan sebelum dan setelah dilakukan terapi menulis ekspresif (n-20)

\begin{tabular}{|c|c|c|c|c|c|c|}
\hline Pengukuran & Min & Max & Mean & SD & IK 95\% & $\mathrm{P}$ value \\
\hline Pre-test & 8 & 28 & 16,5 & 5,862 & \multirow{2}{*}{$5,862-9,367$} & \multirow{2}{*}{0,000} \\
\hline Post-test & 4 & 14 & 8,9 & 3,059 & & \\
\hline \multicolumn{4}{|c|}{$\begin{array}{l}\text { Tabel } 1 \text { menunjukkan tingkat kecemasan } \\
\text { sebelum dilakukan terapi menulis ekspresif } \\
\text { mayoritas mengalami kecemasan tingkat } \\
\text { sedang. Tabel } 2 \text { didapatkan bahwa } 40 \% \\
\text { responden setelah diberikan terapi menulis } \\
\text { ekspresif mengalami kecemasan ringan. Tabel } \\
3 \text { menunjukkan perubahan skor pre-test } \\
\text { dengan skor post-test. Hasil Paired t-test } \\
\text { diperoleh nilai p }=0,000 \text { ( } \mathrm{p}<0,05 \text { ), maka } \\
\text { dapat disimpulkan ada pengaruh terapi menulis }\end{array}$} & \multicolumn{3}{|c|}{$\begin{array}{l}\text { anak perempuan cenderung lebih sering } \\
\text { menjadi korban bullying (Nunung \& Umbu, } \\
\text { 2010). Hal ini dikarenakan adanya pandangan } \\
\text { bahwa anak laki-laki lebih kuat dari anak } \\
\text { perempuan sehingga anak perempuan } \\
\text { cenderung menjadi korban bully. Laki-laki } \\
\text { terlihat lebih mempunyai kekuatan daripada } \\
\text { perempuan sebagai konsekuensi dari } \\
\text { kepercayaan sosial bahwa laki-laki yang lebih } \\
\text { mendominasi dalam segala hal. }\end{array}$} \\
\hline
\end{tabular}

ekspresif terhadap tingkat kecemasan korban bullying.

\section{PEMBAHASAN}

\section{Tingkat kecemasan sebelum pemberian} terapi menulis ekspresif

Kecemasan merupakan respon emosional seseorang yang bersifat subjektif. Kecemasan ditandai dengan perasaan ketakutan, gangguan konsentrasi, menurunnya minat dalam aktivitas yang biasanya dilakukan, merasa tegang, gelisah, cepat marah, resah, kehilangan nafsu makan, serta tidak dapat tidur (Videbeck, 2014). Terdapat $75 \%$ berjenis kelamin perempuan dan $25 \%$ berjenis kelamin laki-laki yang menjadi korban bullying. Anak laki-laki cenderung melakukan tindakan bullying dan
Hasil pre-test (tabel 1) tingkat kecemasan yang dialami oleh siswa korban bullying sebelum pemberian terapi menulis ekspresif diketahui $35 \%$ siswa korban bullying mengalami kecemasan sedang. siswa korban bullying mengalami tanda gejala jantung berdegup (deg-degan), perasaan takut jika bertemu dengan kakak kelas yang melakukan bully, tidak nafsu makan, sulit berkonsentrasi, dan sulit untuk tidur.

Gunawan (2011) menuliskan bahwa tanda gejala tingkat kecemasan sedang menimbulkan respon fisiologis seperti sering napas pendek, tekanan darah dan nadi meningkat, mulut kering, diare atau konstipasi, tidak nafsu makan, mual dan berkeringat.Respon kognitif 
yang muncul akibat ansietas sedang adalah pandangan menjadi menyempit, berfokus pada apa yang menjadi perhatian, dan bingung. Sedangkan, respon perilaku yang muncul pada individu akan menjadi banyak bicara dan lebih cepat, susah tidur, serta merasa tidak aman.

\section{Tingkat kecemasan setelah pemberian terapi menulis ekspresif}

Expressive Writing atau menulis ekspresif adalah sebuah proses terapi dengan menggunakan metode menulis ekspresif untuk mengungkapkan pengalaman emosional dan mengurangi stress yang dirasakan individu sehingga dapat membantu memperbaiki kesehatan fisik, menjernihkan pikiran, memperbaiki perilaku, dan menstabilkan emosi (Qanitatin dkk, 2011). Hasil post-test setelah dilakukan terapi menulis ekspresif terlihat bahwa $40 \%$ responden mengalami penurunan tingkat kecemasan menjadi kecemasan ringan. Tingkat kecemasan menurun pada siswa korban bullying terjadi karena dengan mengikuti kegiatan terapi menulis ekspresif, dapat mengarahkan individu pada pemecahan masalah (Pennebaker, 2007).

Yeni (2013) memaparkan ketika menuliskan peristiwa yang mencekam akan menimbulkan pemahaman baru dan masalah tersebut menjadi bisa lebih dibatasi dan dikelola setelah dituliskan di kertas. Menulis pengalaman emosional dapat menciptakan semacam struktur dan organisasi dalam pikiran. Ketika menulis, proses berpikir seseorang dipaksa untuk mengalami perlambatan dan seseorang mampu membawa satu gagasan ke satu simpulan logisnya.

\section{Perbedaan tingkat kecemasan sebelum dan setelah dilakukan terapi menulis ekspresif.}

Hasil pengujian secara statistik didapatkan skor pre-test nilai minimal 8; maksimal 28; mean 16,50; dan nilai standar deviasi 5,862. Skor post-test nilai minimal 4; maksimal 14; mean 8,90; dan nilai standar deviasi 3,059. Pvalue $=0,000$, dibandingkan dengan nilai koefisien alpha $(\alpha)=0,05$, maka $\mathrm{P}-$ value $<\alpha$. Hal ini dapat disimpulkan bahwa Ha diterima sehingga ada pengaruh terapi menulis ekspresif terhadap tingkat kecemasan pada korban bullying.
Terapi menulis ekspresif memungkinkan responden untuk berekspresi tentang semua yang ada dalam pemikirannya karena menulis adalah suatu aktivitas melahirkan pikiran dan perasaan dalam bentuk tulisan (Susilowati dan Hasanat, 2011). Terapi menulis ekspresif/ menulis pengalaman emosional yang dilakukan juga terbukti efektif untuk menurunkan kecemasan dan menurunkan masalah-masalah kesehatan (Pennebaker \& Chung, 2007). Zahro (2017) bahwa menulis pengalaman atau peristiwa traumatik, stress atau emosional dapat memperbaiki kesehatan fisik dan psikologis seperti mengurangi kecemasan dan menurunkan ketegangan.

\section{SIMPULAN}

Terapi menulis ekspresif memiliki pengaruh terhadap tingkat kecemasan remaja korban bullying.

\section{DAFTAR PUSTAKA}

Harvina, Nunung, dkk. 2010. Hubungan Antara Kebutuhan Berkuasa Dan Tindakan Bullying. Universitas Kristen Satya Wacana. Diperoleh 5 Mei 2017 pukul 20.40 WIB

Ikhsani, Leli Nurul. 2015. Studi Fenomenologi: Dinamika Psikologis Korban Bullying Pada Remaja. Universitas Muhammadiyah Surakarta. Diperoleh 5 Mei 2017 pukul 15.47 WIB

Latifah, Fika. 2012. Hubungan Karakteristik Anak Usia Sekolah Dengan Kejadian Bullying Di Sekolah Dasar X Di Bogor. Fakultas Ilmu Keperawatan Universitas Indonesia Diperoleh 5 Mei 2017 pukul 21.00 WIB

Maramis, Willy F. 2009. Catatan Ilmu Kedokteran Jiwa. Surabaya: Airlangga University Press

Masruroh, N, dkk. 2016. Pengalaman Bullying Berdasarkan Perspektif Pelaku, Korban, dan Saksi Mata Pelajar SMP "X" Kota Batu. Universitas Muhammadiyah Malang. Diperoleh 5 Mei 2017 pukul 12.18 WIB

Murti, Dahlia Reyza. 2013. Pengaruh Expressive Writing Terhadap Penurunan Depresi Pada Remaja SMK di Surabaya. 
Jurnal psikologi Klinis dan Kesehatan Mental.

Pennebaker, J W. 2007. Writing About Emotional Experiences as a Therapeutic Psychological Science. Ed. 8

Pennebaker, J. W., \& Chung C. K. 2007. Expressive Writing, Emotional Upheavals, and Health. New York: Oxford University Press

2007. Expressive Writing: Connections to Physical and Mental Health. New York: Oxford University Press

Putri, Amilda. 2010. Menulis Buku Harian Sebagai Media Katarsis Stress Remaja Di Pelayanan Sosial. Diperoleh 23 Mei 2017 pukul $19.40 \mathrm{WIB}$

Qanitatin, Novi, Sri Widyawati, Gusti Yuli Asih. 2011. Pengaruh Katarsis dalam Menulis Ekspresif Sebagai Intervensi Depresi Ringan Pada Mahasiswa. Jurnal Psikologi Undip.

Rohmadani, Zahro Varisna. Relaksasi dan Terapi Menulis Ekspresif Sebagai Penanganan Kecemasan Pada Difabel Daksa. Universitas Aisyiyah Yogyakarta. Diperoleh 21 Maret 2017 pukul 17.11 WIB

Saifudin, Nur Kholidin. 2015. Pengaruh Terapi Menulis Ekspresif Terhadap Tingkat Kecemasan Siswa Kelas XII Ma Ruhul Amin Yayasan SPMMA (Sumber Pendidikan Mental Agama Allah) Turi di Desa Turi Kecamatan Turi Kabupaten Lamongan. Jurnal STIKes Muhammadiyah Lamongan.

Soedjatmiko, dkk. 2013. Gambaran Bullying dan Hubungannya Dengan Masalah Emosi dan Perilaku Pada Anak Sekolah Dasar. Fakultas Kedokteran Universitas Indonesia. Diperoleh 30 November 2016 pukul 18.40 WIB

Sucipto. 2012. Bullying Dan Upaya Meminimalisasikannya. FKIP Universitas Muria Kudus. Diperoleh 6 Mei 2017 pukul 16.53 WIB
Susanti, Reni dan Sri Supriyantini. 2013. Pengaruh Expressive Writing Therapy Terhadap Penurunan Tingkat Kecemasan Berbicara Di Muka Umum Pada Mahasiswa. Jurnal Psikologi.

Niman, S. 2018. Pengaruh Terapi Menulis Ekspresif Terhadap Tingkat Kecemasan Remaja Korban Bullying. Prosiding Konferensi Nasional Keperawatan Kesehatan Jiwa

Susilowati, Yeni. 2013. Pengaruh Kegiatan Menulis Pengalaman Emosional Terhadap Penurunan Perilaku Agresi Narapidana Di Lembaga Pemasyarakatan Wanita Kelas IIA Malang. Universitas Negeri Malang. Diperoleh 17 Mei 2017 pukul 19.16 WIB

Videbeck, Sheila L.2014. Psychiatric-Mental Health Nursing. Ed. 6. Philippine: Philippines 
Jurnal Keperawatan Jiwa Volume 7 No 2 Hal 179 - 184, Agustus 2019

FIKKes Universitas Muhammadiyah Semarang bekerjasama dengan PPNI Jawa Tengah 